Sosyal Bilimler Dergisi / Cilt: 16, Sayı 1, 2014, 43-64

\title{
Afyonkarahisar'in Rekreasyon Alan Ve Faaliyetlerinin Konaklama Süresi Üzerindeki Etkisi $^{1}$
}

DOI NO: 10.5578/JSS.7508

\author{
Mustafa Sandıkçı ${ }^{2}$ \\ Fatih Günay ${ }^{3}$
}

\begin{abstract}
Özet
Tatil anlaylşı günümüzde sektörel gelişim ve rekabet ile yeni ürünlerin ortaya konmasl, profesyonel turizm hizmeti sunumu gibi nedenlere değişmiştir. Destinasyona bağlı nedenlerin yanı sıra bireysel nedenler de, tatil anlayışının değişmesinde etkili olmuştur. Yapılan bu çalışmada amaç rekreasyon alan ve faaliyetlerin turistlerin konaklama süresi üzerindeki etkisinin incelenmesidir. Afyonkarahisar'ın termal kaynak arzının yoğun olması nedeniyle termal özellikli hizmet veren işletmeler araştırma dişında tutulmuş olup rekreasyon alan ve faaliyetlerinin konaklama süresine etkisi incelenmiştir. Anket aracılığılla toplanan verilerin analizinde frekans-yüzde dağllımları, frekanslara bağlı olarak önem puanı hesaplaması ve bağımsız örneklemler için ki-kare testi kullanılmıştır. Elde edilen bulgulara göre turistlerin konaklama süreleri üzerinde mevcut rekreasyon alan ve faaliyetlerin etkisi düşük düzeyde kalmıştır. Arz ve talebin kimi nedenlerine bağlı olan bu sonuç ile ilgili rekreasyon kaynakları hakkındaki düşünceleri kimi kişisel özelliklere göre analiz edilmiştir. Kimi özelliklerinde istatistikî açıdan anlamlı farklılıklar görülmüştür.
\end{abstract}

Anahtar Kelimeler: Rekreasyon, Turist, Konaklama Süresi, Afyonkarahisar

\footnotetext{
1 “Afyonkarahisar'ın Rekreasyon Alanları ve Faaliyetlerinin Turizm Talebine ve Konaklama Süresine Etkisi” başlıklı Afyon Kocatepe Üniversitesi SBE-Turizm İşletmeciliği ve Otelcilik Anabilim Dalında Yüksek Lisans Tezi olarak yapılan çalışma verilerinden uyarlanmıştır.

${ }^{2}$ Yrd. Doç. Dr., Afyon Kocatepe Üniversitesi, Turizm Fakültesi sandikcimustafa@hotmail.com

${ }^{3}$ Araştırma Görevlisi, Mersin Üniversitesi, Turizm Fakültesi, Turizm İşletmeciliği Bölümü. fgunay@mersin.edu.tr
} 
M. Sandıkçı vd. / Afyonkarahisar'ın Rekreasyon Alan ve Faaliyetlerinin Konaklama Süresi Üzerindeki Etkisi

\title{
The Effects of Afyonkarahisar's Recreational Area and Activities on the Length of Stay
}

\begin{abstract}
The mentality of the holiday has changed by the reason of competition and development of sector. The purpose of this study is to investigate recreational areas and activities' effects on length of stay. Thermal resources were excluded from recreational areas and activities because the thermal sources are the basic preference for the city. Outside recreational areas were investigated. Questionnaire was used as a method of data collection. To analyze data Frequency-Percentage analysis, Calculation importance score of the rated questions by frequencies and ChiSquare for independent samples test was used. According to the findings, participation in the activities does largely not affect the length of stay.
\end{abstract}

Keywords: Recreation, Tourist, The Length of Stay, Afyonkarahisar

\section{Giriş}

Afyonkarahisar termal kaynak zenginliği açısından ülke ölçeğinde belirli bir yere sahiptir. Termal alanların kullanımı bakımından yaşayanlarının yanı sıra turistik tesisler ile ziyaretçilerinin "sudan gelen sağlık"tan yararlanmalarına imkân sunmaktadır. Afyonkarahisar'ı turistik bir destinasyon olarak tercihte termal kaynaklar ana neden olmakla birlikte ilin sahip olduğu termal dışı zenginlikler de termal kaynaklar kadar önemlidir.

Tarihi alanlardan özellikle Frigler'in yaşadığı alanları kapsayan Ankara, Eskişehir, Kütahya'nın da bulunduğu vadide yer alan il aynı zamanda Kurtuluş Savaşı'nın yaşandığı ve kazanıldığı topraklar olarak da anılmaktadır. Flora ve yapısı ile Akdağ'ın yanı sıra su kaynakları da ilin doğal zenginliğinin birer göstergesidir. Afyonkarahisar ayrıca Ege'nin İç Anadolu'ya açılan kapısı ve Akdeniz'e rahat bir yolla gidişin de güzergâhı durumundadır. Bütün bu özellikleri nedeniyle ilin tek bir kaynağının değil bütün değerlerinin turistik arzının gerçekleştirilmesi akılcı olacaktır.

Afyonkarahisar bugün ağırladığı ziyaretçi sayısı bakımından günden güne artış göstermekle birlikte turistik tesislerinde de artış görülmektedir. Buna karşın 2011 y1lında bakanlık belgeli işletmelerin toplam yatak doluluk durumu 161 gün olarak kalmıştır. Termal kaynakların mevsimsellik sorunundan etkilenmeyeceği varsayılsa da düşük doluluk oranıyla birlikte gelen ziyaretçilerin ortalama konaklama süreleri 2,39 gündür (Ünal, 2012).

$\mathrm{Bu}$ çalışmada temel amaç ilin sahip olduğu termal dışı kaynakların konaklama süresine etkisinin durum analizini yapmaktır. Bu amaca yönelik 
frekans ve yüzdeler ile ki-kare testi neticesinde farkl1lıklar ortaya konmuştur. Elde edilen sonuçlar ilin rekreasyon alan ve faaliyetlerinin büyük oranda (alan ve faaliyetlere katılanların \%77.1) konaklama süresine etkisinin olmadığını ortaya koymuştur. Afyonkarahisar ilinin otel dişı rekreasyon alanlarının konaklama süresine etkisini inceleyen araştırma turistlerin tatil sürelerine etkisinin incelenmesi araştırmanın katkılarından biridir. Araştırma turizm sektörü yatırımcıları veya sektöre yönelik ya da sektörle ilgili farklı alanlarda yatırım yapmak isteyenler için faydalı olacak bilgiler sunması da araştırmayı önemli kılmaktadır. Çalışma giriş bölümü dışında literatür (alanyazın) taraması, araştırma metodolojisi, bulgular ve değerlendirmeler ile son olarak sonuç bölümlerinden oluşmaktadır.

\section{Literatür Taraması}

Her canlı gibi biyolojik bir varlık olan insan, yaşamı boyunca fiziksel çevresi ile ilişkilidir. Bu ilişkiyle birlikte insanlar ilkçağlardan bu yana temel fiziksel çevre unsurları ile denge içerisinde olarak bunlardan yararlandığı ölçüde sağlıklı ve mutlu olabilmişlerdir (Aslan, 1993: 22). Bu bağlamda insanlar sahip oldukları boş zamanda rekreasyon faaliyetlerine katılarak ihtiyaçlarını giderecek, sağlı ve mutluluk kazanacaktır. Rekreasyon kavramı yenilenme, yeniden yaratılma veya yapılanma anlamlarındaki Latince kökenli "Recreatio" kelimesinden gelmektedir. Türkçe lügatinde genel olarak boş zamanları değerlendirme olarak kullanılmaktadır. Buradaki kullanımda bireylerin ve toplumsal kümelerin boş zamanlarında gönüllü olarak yaptıkları dinlendirici ve eğlendirici etkinlikler anlamını içermektedir (Ozankaya, 1980: 27). Sağcan (1986: 5) rekreasyonu, insanların boş zamanlarında, eğlence ve tatmin dürtülerini gidermek üzere gönüllü olarak katıldıkları faaliyetler şeklinde tanımlamaktadır. Yapılan bu faaliyetler insanlara, bedensel ve ruhsal yorgunluklarını gidererek fiziksel, ruhsal ve yaratıcı güç kazandırır.

Yapılan tanımlamalar ve özelliklerden hareketle rekreasyonun sınıflandırılmasında kişilerin faaliyetlere katılmasına sebep olan amaçlar, istekler ve zevkler dikkate alınmaktadır. Sinıflandırma, rekreasyonun fonksiyonlarına ve çeşitli kriterlerine bağlı olarak şekillenmektedir. Kişi hangi amaç ve istek doğrultusunda faaliyete karar vermişse buna uygun bir rekreasyon çeşidi ortaya çıkmaktadır. Çok çeşitli istek ve amaçları bulunan insanların yanı sıra çok çeşitli rekreatif etkinliklerin olmasından dolayı, kesin bir gruplandırma ve çeşitlendirme yapmak zordur. Bu sınırlar doğrultusunda rekreasyon, amaçlarına göre ve çeşitli kriterlere göre sınıflandırılabilir (Karaküçük, 2005: 76-77). Sınıflandırma şu şekilde yapılabilir (Hazar, 1999: 29-33); Mekânsal açıdan (açık alan-kapalı alan), Katılımcıların milliyetlerine göre (ulusal-uluslararası), Etkinliklere katılım 
şekline göre (etken-edilgen), Katılımcıların yaş gruplarına göre, Katılımcı sayısına göre (bireysel-grup), Fonksiyonel açıdan (ticari-estetik-sosyalsağlık-fiziksel) şeklinde sınıflandırılmakla birlikte bir faaliyetin kesin bir gruba dâhil edilmesi söz konusu değildir.

İnsanların rekreasyonel etkinliklere katılımındaki artış birtakım sosyal ve ekonomik faktörlere bağlıdır. Rekreatif katılımı teşvik eden sosyal ve ekonomik faktörler şu şekildedir (Sağcan, 1986: 84-89; Aslan, 1993: 24; Karaküçük, 2005: 103; Williams ve Shaw, 2009: 328);
$\checkmark \quad$ Sanayileşme ve kentleşme,
$\checkmark \quad$ Ekonomik verimlilik ve çalışma koşullarındaki gelişmeler,
$\checkmark \quad$ Harcanabilir gelirin artması, nüfus artışı ve hareketliliği,
$\checkmark \quad$ Teknoloji, kitle iletişim araçlarının etkisi, reklam ve propaganda,
$\checkmark \quad$ Kültürel etkileşim, eğitim düzeyi, çevre bilinci,
$\checkmark \quad$ Değişen yeni sağlık bilinci ve isteklerin değişimi,
$\checkmark \quad$ Değerlerdeki değişmeler,
$\checkmark \quad$ Siyasal otorite ve diğer kuruluşların etkileri,
$\checkmark \quad$ Eğlence hareketinin etkisi, sosyal hareketliliğin etkisi,
$\checkmark \quad$ Doğal zenginliklerin etkisi, rekreasyonel merkezlerin artışı,
$\checkmark \quad$ Araç, gereç ve malzemenin teşviki.

Modern toplumlarda görülen kentleşme ve sanayileşmenin etkisi ile insanların boş zaman sürelerinin artış göstermesi insanları rekreasyon faaliyetlerine yöneltmiştir. Endüstrinin büyük yerleşim yerlerinde yoğunlaşması ve azalan çalışma saatleri ile artan boş zamanlar, artan hareket olanakları kentlinin rekreasyon gereksinimlerini büyük boyutlara çıkarmaktadır (Aslan, 1993: 24).

Turizm talebi, "belirli bir piyasada, belirli bir fiyata, turistik mal ve hizmetleri rasyonel ve rasyonel olmayan nedenlerle, kendi konaklama yeri dışında satın alma isteğinde bulunan, bu isteği gerçekleştirmeye imkân verecek kadar satın alma gücüne ve boş zamana sahip olan ve satın almayı gerçekleştiren insan miktarı"dır (Olalı ve Timur, 1988: 195). Tanımdan anlaşılacağ1 üzere turizme özgü talep kavramından söz edebilmek için (Kozak vd., 2001: 62);

\footnotetext{
$\checkmark \quad$ Tüketim zamanının kesin sinırının olması,

$\checkmark \quad$ Tüketimde bulunacak kimsenin belirli bir gelir ve boş zamana sahip olmas1,

$\checkmark \quad$ Turistik mal ve hizmetlerin belirli bir piyasada ve belirli
} 
fiyata turistlerin hizmetine sunulmuş olması, olmas1 gerekir.

Tüketicinin mal ve hizmetlerden yararlanmak için isteğinin

Turizm talebinin diğer bir özelliği ise, turizmde talebin sadece tüketimde bulunan kişilerden oluşmamasıdır. Bu nedenle turizm talebinin üç bileşeni vardır. Turizm destinasyonuna fiilen giderek katılan efektif (fiili) talep, seyahat için uyarılmış ancak zaman veya para gibi nedenlerle isteği gerçekleştiremeyen potansiyel talep ve uyarıldığında seyahat edebilecek ancak mevcut olanaklar ve faaliyetler hakkında yeterli bilgiye sahip olmayan ertelenmiş turizm talebidir (Kozak vd., 2001: 62-63).

Rekreasyonel turizm kavramının kabul görmeye başlamasıyla yapılan tanımlamada ise, insanların boş zamanlarında tekdüzelikten kurtulmak amacıyla; çevrelerinden, yaşam biçimi, yoğunluk veya monotonluğundan belirli süre uzaklaşarak, düşledikleri firsatları değerlendirme, özgürce hareket ederek kendilerini yenilemek üzere gönüllü olarak katıldıkları etkinliklerin tümüdür (Demirci Orel ve Yavuz, 2003: 64).

Turizm talebinin rekreasyon temelli sinıflandirma hususu dikkate alındığında insanların kişisel özelliklerinin talebe ve satın alma kararlarında etkisi olduğunu ortaya koyan kimi çalışmalar (Öter ve Özdoğan, 2005; Avan, 2010) bulunmaktadır. İlgili alanyazında konaklama süresi temelli araştırmalar kısıtlı durumdadır (Alegre ve Pou, 2006: 1345). Konaklama süresine yönelik yapılan kimi çalışmalarda (Opperman, 1995; Seaton ve Palmer, 1997; Sung vd., 2001) farklı turist tiplerinin konaklama sürelerindeki farklılığın tur sonuçlarından nasıl etkilendiği konusuna değinmektedir. Alegre ve Pou (2006) ise Akdeniz'in güneş-kum alanında lider destinasyonlarından biri olan destinasyonda konaklama süresinin mikro ekonomik belirleyicilerini incelemiştir.

Eski çağlardan günümüze kadar insanın doğada ve doğaya bağlı koşullara göre yaşaması insanların çok çeşitli uygarlıklar oluşturmasında etken olmuştur. Bu nedenle özellikle Anadolu'da yaşayan insanlar bölgenin coğrafi yapı özellikleri nedeniyle çeşitli uygarlıklar yaratmışlardır. "Kapalı bölgeler ve doğu batı uzantısı" bu özelliklerden birisi olup Afyonkarahisar'da da bu özelliğin etkisi görülmektedir (İlasl1, 2001: 83).

Geçmişte önemli bir tampon bölge olan Afyonkarahisar yine günümüzde de bir kavşak noktasıdır (İlaslı, 2001: 83; Kaymakçı, 2011: 199). Farklı bölgeler üzerinde yer alan Afyonkarahisar ilinde genellikle karasal iklim görülmektedir. (Afyonkarahisar Belediyesi, 2012). 1902 yılındaki yangın sonrasında padişah II. Abdülhamit tarafından gönderilen 14.000 altın ile dönemin mimarları ve ustalarınca Mevlevihane'yi de kapsayan bölgenin en önemli sivil mimari örneği olan ve birbirine benzemeyen 400 tarihi konak yeniden inşa edilmiştir. İl merkezinde bulunan ve korunması gereken tescilli 
kültür varlığı olan bu tarihi alan günümüze kadar taşınmıştır (Kentsel Sit, b.t.).

İl merkezinde bulunan önemli rekreasyon alanlarının başında Arkeoloji Müzesi, Zafer Müzesi, Sultan Divanî Mevlevihane Müzesi, tarihi yerleşim yeri Çavuşbaş Mahallesi, adına türküler yazılan Karahisar Kalesi, Cumhuriyet Savaşı'nın önemli şahsiyetlerine ve kahraman askerlerinin anısına yapılan Şehitlik ve Anıtlar başlıcalarıdır. Selçuklu ve Osmanlı dönemlerinden günümüze taşınan cami, mescit, köprü, ç̧ş̧me gibi tarihi eserlerin yanı sıra han, kervansaray ve hamamlar günümüze değin taşınmıştır (Afyon Kütügü, 2001; Afyonkarahisar İl Kültür ve Turizm Müdürlüğü, 2012). Son yıllarda sosyal kültürün bir parçası haline gelen modern Alışveriş Merkezlerinden Afium, Zeyland ve Özdilek Alışveriş Merkezleri ile Kent Park1, Zafer Ormanı gibi son dönem rekreasyon alanları sahip olunan kaynaklardandır (Afyonkarahisar Kütüğü, 2001).

İlçelerin sahip olduğu rekreasyon alan ve faaliyetler ise, İhsaniye ve İscehisar'da yoğunluklu bulunan Peribacaları, Bolvadin, İhsaniye ve İscehisar'da bulunan Kaya yerleşimleri (Örn. Kemerkaya, Ayazini, Kırk İnler), tarihi cami, han, külliye ve yapılar ile şehitlikler, doğal oluşum ve güzelliklerden olan Acıgöl, Eber, Emre ve Karabık göllerinin ile Sandıklı ilçesinde bulunan Akdağ Milli Parkı'dır (Afyonkarahisar Kütüğü, 2001).

\section{Araştırma Metodolojisi}

Yapılan bu çalışma ile rekreasyon alan ve faaliyetlerinin konaklama süresine etkisini açıklayarak ortaya koymak ana hedef olmuştur. İllerin sahip olduğu kaynaklarını arz durumu neticesinde talep ve konaklama sürelerinde etkiler görülecektir sorusundan hareketle araştırma sahası olarak seçilen Afyonkarahisar 2011 yılında özellikle termal kaynakların arzı ile büyük çoğunluğu yerli olmak üzere 450 bin dolaylarında turisti ağırlamıştır. $\mathrm{Bu}$ ziyaretçi sayısıyla ilin turizm bakanlığ 1 tesislerinde doluluk oranı 5,5 ay olarak gerçekleşmiştir. Buna karşın ziyaretçilerin konaklama süreleri ise ortalama 2,4 kişi/gündür (Ünal, 2012).

Afyonkarahisar ilinin otel dışı rekreasyon alanlarının konaklama süresine etkisini inceleyen araştırma ile il genelinde sahip olunan rekreasyon kaynaklarının turistlerin tatil sürelerinde bir etkisi olup olmadığının incelenmesi araştırmanın literatüre katkısı olmuştur. Araştırma neticesinde turizm sektörü mevcut yatırımcıları veya sektör içinde ya da sektörle ilgili farklı alanlarda yatırım yapmak isteyenler için faydalı olacak bilgiler sunması da araştırmayı önemli kılmaktadır. Bu gereksinimlerle yapılan araştırmanın temel sorusu aşağıdaki gibi ifade edilebilir. 


\section{"Afyonkarahisar'in rekreasyon alanlar ve faaliyetlerinin konaklama süresi üzerindeki etkisi nedir?"}

Verilerin toplanmasında nicel yöntemlerden olan anket tekniği uygulanmıştır. Kullanılan anket formunun oluşturulmasında insanların rekreasyon davranışları ve rekreasyon alan ve faaliyetlerin kapsamı hakkındaki sorular alanyazındaki (Aytaç, 2002; Mansuroğlu, 2002; Demirci Orel ve Yavuz, 2003; Alegre ve Pou, 2006; Brey ve Lehto, 2007; Sabbağ ve Aksoy, 2011) çalışmalar dikkate alınarak, diğer sorular (konaklama süresine etki, harcama miktarı gibi) ise araştırma sorusuna katkı sağlayacak şekilde ve uzman görüşleri alınarak oluşturulmuştur.

İki bölümden oluşan anketin ilk bölümünde "kişisel özellikler" başlığında on beş soru yer almıştır. Kişisel özellikler sorularında kapalı uçlu olarak "cinsiyet, medeni durum, gelir, öğrenim durumu, meslek, geliş sebebi, eşlikçi, tatil bütçesi" sorulmuşken, kısmen kapalı ve açık uçlu sorularda “yaş, Afyonkarahisar'a yapılan ziyaret sayısı, birlikte gelinen kişi sayısı, çocuk sayısı, geceleme sayısı, gelinen şehir ve konaklama giderlerini kimin karşıladığı" soruları yöneltilmiştir. İkinci bölümde ise kapalı uçlu olarak "boş zaman değerlendirilmesinde tercih edilen kaynaklar, doğal çevrede yapılan rekreasyon eylemleri, Afyonkarahisar'1 tercih nedeni, seyahat öncesi ilin rekreasyon alan ve faaliyetleri hakkında araştırma yapma ve bilgi, rekreasyon alan ve faaliyetlerine katılım gösterenlerin katılım nedenleri ile yapılan harcama ve memnuniyet ile tavsiye düşünceleri; katılım göstermeyenlerin katılmama nedenleri" sorulmuş olup kısmen kapalı ve açık uçlu sorularda ise “Afyonkarahisar'da bilinen rekreasyon alanları ile katılım gösterilen rekreasyon alanları, rekreasyona ayrılan gün ve günlük süre" sorulmuştur.

Hazırlanan anket formu 1-25 Haziran 2012 tarihleri arasında uygulanmıştır. Bu tarihin seçilmesi serbest zaman aktivitelerinin ve turizmin mevsimselliğinden kaynaklanmaktadır. Otel dişı açık alan rekreasyon alan ve faaliyetlerinin ağırlıklı olarak ölçümlenme amacı Haziran ayını seçme nedenlerindendir. Diğer yandan seçilen sürenin araştırmacıya uygunluğu da dikkate alınmıştır. Afyonkarahisar'da geceleme yapan konuklara uygulanan anket için veriler, ilçelerde dâhil olmak üzere ildeki bakanlik belgeli işletmelerden, devre mülk hizmet sunan işletmelerden, belediye ve belediye belgeli özel işletmelerden derlenmiştir. Araştırmada örnekleme yöntemi olarak "Kolayda Örnekleme Yöntemi" uygulanmıştır (Ural ve Kılıç, 2005: 38; Altunışık vd., 2010: 140;). Örneklem büyüklüğü tespit edilirken nicel değişkenler için kullanılan ve sınırsız ya da hacmi bilinmeyen evrenler için dikkate alınan örneklem formülünden yararlanılmıştır. Araştırmada; hata payı, güvenirlik düzeyi ve eksik ya da yanlış kodlama nedeniyle değerlendirilmeye alınmayacak anketlerin olabileceği ve araştırmacının hedef kitleye ulaşma olanakları dikkate alınarak, örneklemin tüm gruplar 
için eşik (sınır) değeri olan n=384 sayısının (Özdamar, 1999: 260) üzerine çıkılarak 405 kullanılabilir anket formuna ulaşılmıştır.

Araştırma sorusunda belirtilen etkinin nedenlerinin ortaya konulması için tanımlayıcı istatistiksel analiz türlerinden frekans ve yüzde testleri uygulanmıştır. Katılımcıların farklılıklarının kaynağının ortaya konulması amacıyla rekreasyona katılma durumları, talep durumu, bilgi düzeyleri gibi sorularda yanitlayıcılarca önem siralamasina konulan cevaplar ters puanlama ile Önem Puanı [ÖP] oluşturulmuştur. Oluşturulan puanlara göre sıralama yapılan veriye yönelik katılımcılar arasında bir farklılık olup olmadığını ortaya koymak üzere parametrik olmayan testlerden "Ki-Kare" ile test edilmek üzere, ilgili veriler gruplandırılmıştır. Frekans ve yüzde sonuçları ile etki durumlarının nedenleri Ki-Kare testi sonuçlarına göre ise farklılıklar ortaya konulmuştur.

\section{Bulgular ve Değerlendirme}

Ankette katılımcılara yöneltilen kişisel özelliklerle ilgili soruları verilen yanttlara ilişkin frekans ve yüzde değerler tablolarda sunulmuştur. Elde edilen verilere göre katılımcıların \%53,6's1 erkek, \%75,2'si evli bireylerdir. 20-43 yaşları aralığında ve daha önce ziyaret etmemiş 701 TL ile 2200 TL arasında gelir düzeyi olan bireyler çoğunluktadır (tablo-1).

Tablo-1. Kişisel Özelliklere İlişkin Frekans ve Yüzde Dă̆ıllımları-1

\begin{tabular}{|c|c|c|c|c|c|}
\hline Yaş & $\mathbf{f}$ & $\%$ & Gelir & $\mathbf{f}$ & $\%$ \\
\hline 19 ve alt1 & 13 & 3,4 & $1200 \mathrm{TL}$ ve altı & 100 & 25,1 \\
\hline $20-25$ & 41 & 10,7 & $1201-2200 \mathrm{TL}$ & 145 & 36,5 \\
\hline $26-31$ & 72 & 18,8 & $2201-3200 \mathrm{TL}$ & 77 & 19,4 \\
\hline $32-37$ & 78 & 20,4 & $3201-3700 \mathrm{TL}$ & 23 & 5,8 \\
\hline $38-43$ & 53 & 13,8 & 3701 TL üstü & 53 & 13,3 \\
\hline $44-49$ & 33 & 8,6 & \multicolumn{3}{|c|}{ Önceki Ziyaret } \\
\hline $50-55$ & 34 & 8,9 & Yok & 158 & 39,5 \\
\hline $56-61$ & 31 & 8,1 & $1 \mathrm{kez}$ & 37 & 9,3 \\
\hline 62 ve üzeri & 28 & 7,3 & $2 \mathrm{kez}$ & 54 & 13,5 \\
\hline \multicolumn{3}{|c|}{ Cinsiyet } & $3 \mathrm{kez}$ & 24 & 6,0 \\
\hline Kadın & 188 & 46,4 & $4 \mathrm{kez}$ & 16 & 4,0 \\
\hline Erkek & 217 & 53,6 & $5 \mathrm{kez}$ & 23 & 5,8 \\
\hline \multicolumn{3}{|c|}{ Medeni Hali } & $6-9 \mathrm{kez}$ & 17 & 4,4 \\
\hline Evli & 304 & 75,2 & $10+\mathrm{kez}$ & 71 & 17,8 \\
\hline Bekâr & 100 & 24,8 & & & \\
\hline
\end{tabular}


Katılımcıların eğitim durumlarının ortaöğretim ve önlisans/lisans düzeyinde yoğunlaştığı, 1-5 kişi olarak gelenlerin çocuk sayıları hiç çocuksuz ve 1-2 çocuğa sahip olanlardan oluştuğu görülmüştür. Konaklama süresi ise 1-3 gün olarak yoğunlaşmıştır (tablo-2).

Tablo-2. Kişisel Özelliklere İlişkin Frekans ve Yüzde Dağılımları-2

\begin{tabular}{|c|c|c|c|c|c|}
\hline Eğitim & $\mathbf{f}$ & $\%$ & Kişi Sayısı & $\mathbf{f}$ & $\%$ \\
\hline İlkokul/İlköğr. & 76 & 18,8 & Yalnız & 55 & 13,6 \\
\hline Ortaöğr. & 118 & 29,2 & 1-2 kişi & 120 & 29,7 \\
\hline Önlisans/Lisans & 159 & 39,4 & 3-5 kişi & 138 & 34,2 \\
\hline Lisansüstü & 51 & 12,6 & 6 ve üstü & 91 & 22,5 \\
\hline \multicolumn{3}{|c|}{ Konaklama Süresi } & \multicolumn{3}{|c|}{ Çocuk Sayısı } \\
\hline 1-3 gün & 170 & 43,7 & Yok & 223 & 55,2 \\
\hline 4-6 gün & 120 & 30,8 & 1-2 çocuk & 143 & 35,4 \\
\hline 7-9 gün & 49 & 12,6 & 3-5 çocuk & 33 & 8,2 \\
\hline 10-12 gün & 28 & 7,2 & 6 ve üstü & 5 & 1,2 \\
\hline 13-15 gün & 18 & 4,6 & & & \\
\hline 16 gün ve üzeri & 4 & 1,0 & & & \\
\hline
\end{tabular}

Meslek durumları ise özel sektör çalışanı olarak yoğunlaşmış ve 201-800 TL ile 2001 TL ve üzeri bütçeye sahiptirler. Tatil giderlerini ise kendisi karşılayanların oranı fazladır. Gelinen şehir olarak özellikle Ankara en fazla gelinen şehirdir (tablo-3).

Tablo-3. Kişisel Özelliklere İlişkin Frekans ve Yüzde Dağılımlart-3

\begin{tabular}{|c|c|c|c|c|c|}
\hline Gideri Karşılayan & f & $\%$ & Meslek & $\mathbf{f}$ & $\%$ \\
\hline Kendisi & 210 & 52,5 & Kamu Çal. & 84 & 20,8 \\
\hline Kurumu & 25 & 6,3 & Özel Sektör Ç. & 125 & 30,9 \\
\hline Şirketi & 50 & 12,5 & Serbest Meslek & 62 & 15,3 \\
\hline Aile Üyesi & 115 & 28,8 & Emekli & 52 & 12,9 \\
\hline & & & Çalışmıyor+Diğer & 81 & 20,1 \\
\hline \multicolumn{6}{|c|}{ Tatil Bütçesi } \\
\hline 200 TL ve alt1 & 25 & 6,5 & $1101-1400 \mathrm{TL}$ & 43 & 11,2 \\
\hline $201-500 \mathrm{TL}$ & 84 & 21,8 & $1401-1700 \mathrm{TL}$ & 15 & 3,9 \\
\hline $501-800 \mathrm{TL}$ & 80 & 20,8 & $1701-2000 \mathrm{TL}$ & 20 & 5,2 \\
\hline $801-1100 \mathrm{TL}$ & 49 & 12,7 & 2001 TL ve üzeri & 69 & 17,9 \\
\hline \multicolumn{6}{|c|}{ Gelinen Şehir } \\
\hline$\overline{\text { Adana }}$ & 13 & 3,5 & Mersin & 14 & 3,8 \\
\hline Afyon İlçeleri & 36 & 9,8 & İstanbul & 28 & 7,6 \\
\hline Ankara & 63 & 17,2 & İzmir & 14 & 3,8 \\
\hline Bursa & 15 & 4,1 & İzmit & 13 & 3,5 \\
\hline Eskişehir & 38 & 10,4 & Konya & 29 & 7,9 \\
\hline Isparta & 13 & 3,5 & Diğer & 91 & 24,7 \\
\hline
\end{tabular}


Katılımcıların kişisel özelliklerinin betimlendiği sorulardan olan geliş sebebine ilişkin yanıtlarından alınan frekans değerlerine göre önem sıralaması yapılmak üzere önem puanı belirlenmiştir. Ortaya çıkan sonuçlara göre (tablo-4) Afyonkarahisar'1 ziyaret eden turistlerin geliş sebepleri tatil, sağlık, iş, aile-akraba ziyareti, diğer (yol üstü olması gibi) ve rekreasyon amaçlı şeklinde sıralanmıştır. Otel içi konaklama ve termal alanlardan yararlanmayı kapsayan Tatil önemli bir geliş sebebi iken, otel dışı il rekreasyon alan ve faaliyetleri neredeyse önemsiz bir sebeptir. Araştırma anketi dâhilinde sorulan ikinci kısımda öncelikle bireylerin günlük hayatta boş zamanlarını değerlendirmelerine yönelik rekreasyon kaynakları tercihlerinde birden beşe bir sıralama yapmaları istenmiştir. Siralamas 1

Tablo-4. Geliş Sebebine İlişkin Frekans-Yüzde Dağılımları ve Önem

\begin{tabular}{|c|c|c|c|c|c|c|}
\hline \multirow[b]{2}{*}{ Gruplar } & \multicolumn{2}{|c|}{ Birincil } & \multicolumn{2}{|c|}{ İkincil } & \multirow[t]{2}{*}{ Önem Puanı } & \multirow[t]{2}{*}{ Önem Surası } \\
\hline & f & $\%$ & f & $\%$ & & \\
\hline Tatil & 252 & 62,4 & 9 & 13,4 & 1,23 & 1 \\
\hline Sağlık & 61 & 15,1 & 31 & 46,3 & 0,38 & 2 \\
\hline İş & 64 & 15,8 & 9 & 13,4 & 0,34 & 3 \\
\hline $\begin{array}{c}\text { Aile/Akraba } \\
\text { Zivareti }\end{array}$ & 15 & 3,7 & 15 & 22,4 & 0,11 & 4 \\
\hline Diğer & 12 & 3,0 & 1 & 1,5 & 0,06 & 5 \\
\hline Rekreasyon Amaçlı & 0 & - & 2 & 3,0 & 0,01 & 6 \\
\hline
\end{tabular}

Anketin ikinci bölümünde yer alan sorulardan olan günlük hayatta boş zaman değerlendirmeye yönelik tercih edilen rekreasyon kaynakları sorusuna alınan yanıtlara göre ilk beş sırayı Bedensel/Sportif faaliyetler (ÖP:2,51), Alışveriş (ÖP:2,27), Doğal çevre faaliyetleri (ÖP:2,20), Tarihi mekânların ziyareti (ÖP:1,78) ve Kır gezileri (ÖP:1,41) oluşturmuştur. Bir diğer soruda turistlerin doğal çevrede yaptığı rekreasyon eylemlerinden ilk beş tercihini sıralaması istenmiştir. Sonuçlara göre ilk beşi Yürüyüş (ÖP:3,001), Piknik (ÖP:2,849), Dinlenme (ÖP:2,094), Otomobil gezintisi (ÖP:1,851) ve Milli park/Tabiat park1 ziyareti (ÖP:1,199) olarak sıralanmıştır. Turistler Afyonkarahisar's tercih etme nedenlerini sıraladıklarında ise sonuçlar; Termal kaynaklar, Yakın oluşu, Sağlık/Tedavi nedeniyle, Ekonomik oluşu ve Doğal güzellikleri şeklindedir. Rekreasyon amaçlı görmek/yapmak istediklerimin bulunması ise son sırada yer almıştır.

Katılımcılara seyahatleri öncesi bilgi araştırması yapma durumları sorulduğunda katılanların \%71,7'si araştırma yapmadığı görülmüştür. Araştırma yapanlar ise çoğunlukla konaklayacakları işletme web sayfaları ve arkadaş-akraba deneyimlerden bilgi edinmişlerdir. Afyonkarahisar'ın 
rekreasyon alanlarından bildiklerinden dördünü sıralamaları istendiğinde verilen yanıtlara göre en fazla bilinen alan siralaması; Karahisar Kalesi (ÖP:2,22), Afium AVM (ÖP:1,81), Özdilek AVM (ÖP:0,91), Kocatepe (ÖP:0,79) ve Frig Kaya yerleşimleridir (ÖP:0,69). Rekreasyon alanlarına kat1lım oranı ise \%20,75 (f:83)'tir. Turistlerce en fazla gidilen alanların sıralaması yapıldığında (tablo-5) Afium AVM, Karahisar Kalesi, Çavuşbaş tarihi evler ve yerleşim yeri, Frigya-Kaya yerleşimleri, Frigya-Peri bacaları ve Zafer müzesi olarak sıralanmıştır.

Tablo-5. Gidilen Alanlara İlişkin Frekanslar ve Önem Stralaması

\begin{tabular}{ccccccccc}
\hline Gruplar & $\mathbf{f}_{\mathbf{1}}$ & $\mathbf{f}_{\mathbf{2}}$ & $\mathbf{f}_{\mathbf{3}}$ & $\mathbf{f}_{\mathbf{4}}$ & $\mathbf{f}_{\mathbf{5}}$ & $\mathbf{f}_{\mathbf{6}}$ & $\begin{array}{c}\text { Önem } \\
\text { Puanı }\end{array}$ & $\begin{array}{c}\text { Önem } \\
\text { Sirasi }\end{array}$ \\
\hline Afium AVM & 25 & 7 & 6 & 8 & 1 & - & 3,54 & 1 \\
Karahisar Kalesi & 15 & 3 & 8 & 2 & 5 & 1 & 2,67 & 2 \\
Çavuşbaş & 6 & 5 & 14 & 4 & - & 2 & 2,35 & 3 \\
Kaya Yerleşimleri & 12 & 7 & 1 & 4 & 5 & - & 2,30 & 4 \\
Peri Bacaları & 2 & 13 & 5 & 1 & 3 & 5 & 2,27 & 5 \\
Zafer Müzesi & 3 & 12 & 1 & 2 & - & 1 & 1,44 & 6 \\
Özdilek AVM & 4 & 4 & 1 & 7 & - & - & 1,22 & 7 \\
Tarihi Camiler & 2 & 6 & 3 & 2 & - & 3 & 1,21 & 8 \\
Park vb. Yürüyüş Alanları & 6 & - & 2 & 2 & - & - & 0,75 & 9 \\
Arkeoloji Müzesi & 1 & 3 & 3 & - & 1 & - & 0,63 & 10 \\
Diğerleri & 6 & 5 & 8 & 7 & 5 & 2 & & \\
\hline Toplam & 82 & 65 & 52 & 39 & 20 & 14 & & \\
\hline
\end{tabular}

Rekreasyona katılım amaçlarında sıralama Aileyle zaman geçirmek (ÖP: 2,69), Eğlenmek (ÖP: 2,39), Sağlık/Egzersiz amaçlı (ÖP: 1,68), Rahatlama arayışı (ÖP: 1,65) ve Yeni şeyler öğrenmek (ÖP: 1,45) şeklindedir. Rekreasyon için gün ayırmayanların oranı \% 12,5 (f: 10) iken en az 1 gün ve üzeri ayıranlar \% 87,75 (f: 70) olarak görülmüştür. Bunun içinde en fazla 1-3 gün arası ayıranlar (f: $38 \% 60,1)$ 'dır. Rekreasyona katılanların katılım nedeniyle yaptıkları harcama ise tablo-6'daki gibi görülmüşken rekreasyona katılanların \%77,1'inde konaklama sürelerine bir etki görülmemiş, \%12'sinde ise sadece 1 gün konaklama sürelerini uzatmıştır. 
M. Sandıkçı vd. / Afyonkarahisar'ın Rekreasyon Alan ve Faaliyetlerinin Konaklama Süresi Üzerindeki Etkisi

Tablo-6. Turistlerin Rekreasyon Harcamalart ve Katılımın Konaklama Süresine Etkisine İlişskin Frekanslar ve Yüzde Oranları

\begin{tabular}{ccc|ccc}
\hline Rekreasyon Harcama & f & $\boldsymbol{\%}$ & Konaklama Süresine Etkisi & f & $\boldsymbol{\%}$ \\
\hline 200 TL ve altı & 22 & 26,5 & Yok & 64 & 77,1 \\
$201-400 \mathrm{TL}$ & 23 & 27,7 & 1 Gün & 10 & 12,0 \\
$401-600 \mathrm{TL}$ & 18 & 21,7 & 2 Gün & 1 & 1,2 \\
$601-700 \mathrm{TL}$ & 8 & 9,6 & 3 Gün & 2 & 2,4 \\
701 TL ve üzeri & 12 & 14,5 & 4 Gün & 3 & 3,6 \\
& & & 5 Gün ve üzeri & 3 & 3,6 \\
\hline
\end{tabular}

Rekreasyon alanlarına gidenlerin mevcut kaynakların yeterliliği sorusuna verdikleri yanıtlara göre "yeterli" görenlerin oranı $\% 30,1$, "kararsız" olanlar \%26,5'tir. "Yetersiz" olduğunu belirtenlerin oranı ise $\% 43,4$ 'tür. Rekreasyon alanlarına gidenlerin bu kaynaklardan duydukları memnuniyetlerine ilişki bulgulara göre ise memnun olanların oranı \%68,7 iken, kararsız olanlar \%25,3 memnun olmayanların oranı ise \%6'dır. Rekreasyon alan ve faaliyetlere katılanların, bu kaynakları çevrenize tavsiye eder misiniz sorusuna verdikleri yanitlara göre, yantlayanların $\% 57,8^{\prime} \mathrm{i}$ "tavsiye ederim", \%37,3'ü "kısmen tavsiye ederim" ve \%4,8'i ise "tavsiye etmem" şeklinde belirtmiştir.

Araştırmaya katılanlara rekreasyona katılmama nedenlerine ilişkin sorulan soruda katılımcılardan yanıtlarını birden beşe önem derecesine göre sıralamaları istenmiştir. Elde edilen verilere göre katılmama nedenleri Zaman yetersizliği (ÖP: 3,3), Tanıtım eksikliği (ÖP: 2,6), BilgiBilgilendirme eksikliği (ÖP: 2,0), Ulaşım yetersizliği (ÖP: 1,4) ve Tesis yetersizliği (ÖP: 1,3) olarak sıralanmıştır.

$\mathrm{Bu}$ bilgilerin yanı sıra araştırmada elde edilen verilerden kişisel özellikler ile ankette yer alan ikinci bölümdeki rekreasyonla ilgili değişkenleri oluşturan gruplar arasında istatistikî açıdan anlamlı farklılığın olup olmadığına bakılmıştır. Bu amaçla yapılan ki-kare bağımsızlık testi sonuçlarına göre elde edilen veriler 1şığında şu özellikler arasındaki farklılıklar istatistikî açıdan anlamlı bulunmuştur (tablo-7).

Tercih nedeni geliş sebebi arasındaki farklılıklar incelendiğinde özellikle destinasyona dayalı nedenlerle tercih edenlerin tatil sebebiyle gelenler iken iş, toplantı vb. sebeplerle gelenler kişisel nedenlerle tercih etmişlerdir. Yine aile ve akraba ziyareti sebebiyle gelenlerin tercih nedeni destinasyona dayalıdır. Eşlik edenler ve geliş sebebine bakıldığında yalnız ve 3-5 kişi gelenlerin tercih nedeni kişisel olarak yoğunlaşmakta olup, 1-2 ile 6 ve üzeri kişi olanlar destinasyona dayalı nedenlerle tercih etmişlerdir. 
Geceleme sayısı ve tercih nedenine bakıldığında yoğunlukla destinasyona dayalı nedenlerle gelenler görülmekte olup 13 ve üzeri gelenler kişisel nedenlerle tercih etmişlerdir. Gelinen şehirlere göre ise $350 \mathrm{~km}$ mesafeye kadar uzaklıktan gelenler kişisel nedenlerle gelmişken 351 ve üzeri mesafeden gelenler yoğunlukla destinasyona dayalı nedenlerle tercih etmişlerdir. Genel olarak düşük bütçeyle gelenler kişisel nedenlerle tercih etmişken yüksek bütçeli kişiler destinasyona dayalı nedenlerle tercih etmişlerdir. Seyahat giderlerini kendi karşılayanlar destinasyona dayalı nedenlerle tercih etmişken, kurum veya şirketçe karşılananlar kişisel nedenlerle tercih etmiştir.

Tablo-7. Kişisel Özellikler ve Rekreasyon Değişkenleri Arasındaki Farklılık Testi Sonuçları

\begin{tabular}{|c|c|c|c|c|c|}
\hline $\begin{array}{c}\text { Farklılık } \\
\text { Bulunanlar }\end{array}$ & $\begin{array}{l}\text { Tercih } \\
\text { Nedeni }\end{array}$ & $\begin{array}{l}\text { Bilinen } \\
\text { Alanlar }\end{array}$ & $\begin{array}{c}\text { Katılım } \\
\text { Durumu }\end{array}$ & $\begin{array}{l}\text { Gidilen } \\
\text { Alanlar }\end{array}$ & $\begin{array}{c}\text { Katulmama } \\
\text { Nedeni }\end{array}$ \\
\hline \multirow{6}{*}{$\begin{array}{c}\text { Pearson } \\
\text { Ki-Kareye } \\
\text { Göre } \\
\text { Gruplar } \\
\text { Arasinda } \\
\text { Farklılık } \\
\text { Gösteren } \\
\ddot{O}_{\text {zellikler }}\end{array}$} & $\begin{array}{c}\text { Geliş Sebebi } \\
(, 000)\end{array}$ & $\begin{array}{c}\text { Geliş } \\
\text { Sebebi } \\
(, 003)\end{array}$ & Yaş $(, 008)$ & $\begin{array}{c}\text { Giderleri } \\
\text { Karşllayan } \\
(, 021)\end{array}$ & $\begin{array}{c}\text { Geceleme } \\
\text { Sayıs }(, 006)\end{array}$ \\
\hline & $\begin{array}{c}\text { Eşlik Eden } \\
\text { Sayısı (,010) }\end{array}$ & $\begin{array}{l}\text { Çocuk } \\
\text { Sayısı } \\
(, 017)\end{array}$ & $\begin{array}{l}\text { Çocuk } \\
\text { Sayısı } \\
(, 042)\end{array}$ & $\begin{array}{c}\text { Bilinen } \\
\text { Alanlar } \\
(, 000)\end{array}$ & $\begin{array}{c}\text { Ayrulan } \\
\text { Bütçe }(, 001)\end{array}$ \\
\hline & $\begin{array}{c}\text { Geceleme } \\
\text { Saylsl }(, 000)\end{array}$ & $\begin{array}{c}\text { Tercih } \\
\text { Nedeni } \\
(, 000)\end{array}$ & $\begin{array}{c}\text { Geceleme } \\
\text { Saylst } \\
(, 002)\end{array}$ & $\begin{array}{c}\text { Yeterlilik } \\
\text { Algisı } \\
(, 004) \\
\end{array}$ & $\begin{array}{c}\text { Araştırma } \\
\text { Durumu } \\
(, 016) \\
\end{array}$ \\
\hline & $\begin{array}{c}\text { Gelinen } \\
\text { Şehir } \\
(\text { Mesafe }) \\
(, 000)\end{array}$ & & $\begin{array}{c}\text { Ayrllan } \\
\text { Bütçe } \\
(, 001)\end{array}$ & $\begin{array}{c}\text { Gelinen } \\
\text { Şehir } \\
(\text { Özellik) } \\
(, 040)\end{array}$ & $\begin{array}{c}\text { Giderleri } \\
\text { Karşılayan } \\
(, 019)\end{array}$ \\
\hline & $\begin{array}{c}\text { Ayrılan } \\
\text { Bütçe }(, 000)\end{array}$ & & $\begin{array}{c}\text { Geliş } \\
\text { Sebebi } \\
(, 000)\end{array}$ & & \\
\hline & $\begin{array}{c}\text { Gider } \\
\text { Karşılayan } \\
(, 000)\end{array}$ & & & & \\
\hline
\end{tabular}

Öte yandan tatil sebebiyle gelenler yoğunluklu olarak Tarihi alanlar, AVM ve Yöresel lezzetleri ve Kurtuluş savaşı alanları ve müzeleri bilmekte iken, diğer sebeplerle gelenler doğal alanları daha fazla bilmektedir. Birinci grup olan Tarihi alanlar ile Kurtuluş savaşı alanları ve müzeleri bilenler ya çocuksuz ya da 3 ve üzeri çocuğa sahipken, 1-2 çocuklu bireyler genellikle ikinci grup olan doğal alanlar ve AVM ve yöresel lezzetleri bilmektedir. Kişisel nedenlerle tercih edenler daha çok birinci grup alanları bilirken, destinasyona dayalı nedenlerle gelenler genellikle ikinci grup alanları bilmektedir. 
Yaşa göre katılımın en yoğun olduğu yaş grupları 25 ve altı ile 38-49 yaş aralığında görülmüştür. Çocuksuz olanlar ile 6 ve üzeri çocuğa sahip olanlar yine fazlaca katılım gösteren gruplardır. Diğer yandan özellikle 1012 gece konaklayanlar yoğun katılım gösteren grup olmuştur. Tatil bütçesi 1401-1700 TL ile 2001 TL ve üzeri olanların katılım oranları daha fazla iken diğer gruplarda katılım oranı düşük kalmıştır. Diğer sebepler ile aile, akraba ziyareti sebebiyle gelenlerin içindeki katılanlar yine yüksek orandadır. Özellikle ikinci grup alanları ziyaret edenler şahsen giderlerini karşılayanlar olup, kurum veya şirketçe giderleri karşılananlar birinci grup alanlara gitmişlerdir. Elde edilen bir diğer sonuçta bilinen alanların ziyareti doğru yönlü olarak görülmüştür. Yeterli görme düşüncelerine göre bakıldığında yeterli ve yetersiz görenlerin yoğunlukla ikinci grup alanları ziyaret ettiği, kararsız olanların ise birinci grup alanları ziyaret ettiği görülmüştür. Bir diğer önemli bulgu ise büyük şehirlerden gelenlerin ikinci grup alanları küçük şehirlerden gelenlerin ise birinci grup alanları yani tarihi alanlar ve kurtuluş savaşı alanları ile müzeleri ziyaret ettiği görülmüştür.

Katılmama nedenlerine bakıldığında özellikle kişisel nedenler öne çıkmakta olup özellikle 1-3 gece konaklayanlar bu grupta yoğunlukludur. Ayrılan bütçeye göre bakıldığında kişisel nedenlerle katılmayanlar yoğunlukta olup 1101-1400 TL ile 1701-2000 TL ayıranlar destinasyona dayalı nedenlerle katılmamıştır. Son olarak farklılıklar incelendiğinde birinci grup alanların konaklama süresine etkisinin daha fazla olduğu, etkisi olmayanların ise yoğunluklu olarak ikinci grup alanları ziyaret ettiği görülmüştür. Elde edilen veriler ışığında rekreasyon alan ve faaliyetlerinin turizm talebine etkisini düşük oranda kalmıştır. Mevcut kaynakların pazarlanması sorunu, alt ve üst yapı yatırımlarının gerekliliği ortaya koyulmuştur.

\section{Sonuç}

Bireyin günlük yaşamında serbest zamanını kendince etkili bir şekilde geçirmesi kişinin mutlu, çalışma yaşamında daha verimli olmasını sağlar. Tatil ihtiyacı da mutluluğa ve yenilenmeye katkı sağlar. 2011 yılı verileri incelendiğinde bakanlık belgeli işletmelerde geceleme süresi Türkiye ortalaması 3,2 kişi/gün iken Afyonkarahisar'da 2,2 kişi/gün, belediye belgeli işletmelerde geceleme süresi Türkiye ortalaması 2,2 kişi/gün iken Afyonkarahisar'da 2,7 gündür (Kültür ve Turizm Bakanlığı, 2012; Ünal, 2012). Afyonkarahisar otellerinin doluluk oranının düşük kalması yatırımların atıl kapasite olarak çalıştıklarının bir göstergesidir. Kervankıran (2011: 317-320) çalışmasında Afyonkarahisar'ın turizm arzının termal kaynaklara bağlı olduğuna ve "turistik merkez yaşam devri modeli”ne (Butler, 1980: 7) göre Afyonkarahisar'ın Gelişim (Katılım) devresinde 
olduğunu ortaya koymuştur. Çalışma ayrıca Afyonkarahisar'da tanıtım ve iyi pazarlamanın eksiklik olduğunu ortaya koymuştur.

Otel işletmelerinin yanı sıra devre mülk tatil ve konut edindirme arzının da bulunması bölgenin konaklama kapasitesini artırmaktadır. Bu işletmelere sürekli olarak gelerek tatillerini geçiren bireylerin tatil sırasında katlandıkları konaklama giderlerinin düşük olması nedeniyle zamanlarını geçirmeye yönelik alternatif faaliyetler arayışında olması olasıdır. Araştırma kapsamında devre mülk konutlarında konaklayan bireylerin özellikle belediyenin iyi çalışması ve çevrede görülebilecek, zaman geçirilebilecek alan düzenlemeleri yönündeki arzuları göz ardı edilemeyecek düzeydedir.

Yerel yönetimlerin, turizm sektörü ihtiyaçlarından uzak, yerli halk ihtiyaçları odaklı yönetim anlayışı doğru bir yaklaşım değildir. Turizm alanında yapılan her bir yatırım yerli halka bir değer olarak geri dönecektir. Araştırma kapsamında soru yöneltilen alanlarda konaklayan turistlerin yerel yönetimler konusunda sıkıntı yaşandığı da görülmüştür. Çevre düzenlemesi, temizlik, iç açıcı-ferah bir atmosfer ve ulaşım en fazla sıkıntı yaşanan konulardandır.

Rekreasyon etkinliklerine katılımın bireylerin kişisel özelliklerine göre farklılık göstermesi rekreasyonun doğasından kaynaklanmaktadır (Argan, 2007: 28-46). Bulgulardan hareketle, özellikle eksikliği ve yetersizliği belirten genç ve ziyaretçi oranında büyük paya sahip orta yaş düzeyindeki bireylerin ilgilenebileceği bedensel ve sportif faaliyet ve kaynakların arzı ve pazarlanması yerinde bir karar olacaktır. Evli ve çekirdek aile olarak gelen turistler için yapılabilecek ve katılabilecek faaliyetlerin zenginleştirilip etkin bir şekilde tanıtılması sayesinde "ailece güzel ve hoş vakit geçirilebilen şehir" imajı yaratılacaktır. Yalnız ve bekâr bireylerin açık uçlu öneri kısmında belirttikleri "şehir içerisinde güzel vakit geçirebilecek mekânların bulunmaması" şeklindeki ifadeleri destinasyona dayalı sorunların varlığına işaret etmektedir.

Ziyaretçilerin kişisel özelliklerinin çeşitliliği boş zaman aktivite ihtiyaçlarının da çeşitli olduğuna işaret etmektedir. Bu doğrultuda özellikle genç ziyaretçilerin hareketlilik aradığı ortam ihtiyaçlarına cevap verecek herhangi bir alan ve faaliyetin olmaması bir eksikliktir. Diğer yandan yerel sivil toplumun etkin bir şekilde çalıştı̆̆ 1 ve faaliyet gösterdiği dağcılık, doğa gezginleri gibi kulüplerin sektör ile işbirliğinin sağlanması, gerekli desteğin verilmesi özellikle genç turistlerin doğal alanlara olan ilgi ve katılımlarını arttıracak, ihtiyaçlarına cevap verecektir.

Aile çevrelerinden gruplar halinde gelenlerin oranı, mevcut kültürel alan ve faaliyetlerin etkin tanıtım ve ulaşılabilirliği ile düşük oranda kalan katılımın arttırılmasına bir kaynak olacaktır. Çocuklar ve çocuklu aileler için mevcut kaynakların arzı ve pazarlama çabalarının yeterliliği hususu da 
dikkat gerektiren konulardandır. Geceleme sayılarına bakıldığında turistlerin öncül ihtiyaçları sonrasında rekreasyon alan ve faaliyetlerine katılım için yeterli süreye sahip olduklarının göstergesidir. Büyükşsehirlerin keşmekeş trafiği, havası, kalabalığ 1 gibi nedenlerle bu şehirlerden gelen turistler için ilin sahip olduğu doğal (Akdağ, göller) ve tarihi-doğal (Frig vadisi) alanlarına düzenlenecek turlar, küçük ölçekli tesis yatırımları ve bu alanlarda düzenlenecek faaliyet ve yürüyüşlerle insanların yeniden canlanmaları ve büyükşehirlerde yüklendikleri gerilimden kurtulmaları sağlanacaktır.

Elde edilen bulgular Öter ve Özdoğan (2005: 131) tarafından yapılan araştırma bulgularıyla kısmen örtüşmektedir. Bulgulara göre Efes-Selçuk bölgesini ziyaret edenlerin kişisel özelliklerine bakıldığında, eğitim düzeylerinin lise ve üzerinde yoğunlukta olup belirli bir gelire sahip ücretli çalışanlardır. Ziyaretçilerin tura katılım amaçları ise yoğunlukla, bölge kültürünü tanıma isteği, yeni şeyler öğrenme isteği ve yöre ortamını yaşama isteğidir. Araştırmada ayrıca bölge imajının ziyaretçilerce nasıl algılandığına yönelik bulgularda yörenin tarihi mimari özellikleri ve görülecek eşsiz yerlerinin bulunması ön plana çıkmıştır. Bunları takiben, müze ve kültürel çekicilikler, yerel halkın misafirperverliği, kültürel olarak farklı bir bölge olması, çok kültürlü olması, dil çeşitliliği, hareketli ortam ve yerel mutfak şeklinde sıralanmıştır (Öter ve Özdoğan, 2005: 133). Bu özelliklere bakıldığında bir bölgenin tarihi mimari özellikleri, görülesi yerleri, müze ve kültürel çekicilikleri gibi nedenlerle bölgeye olan talebin yoğunlaşmasında etkilidir.

Kurtuluş savaşına sahne olan ve ülke genelinde topyekûn bir mücadele neticesinde kazanılan tam bağımsız bir Cumhuriyet için çetin savaşların yaşandığı alanların tarihi ve kültürel anlamdaki öneminin konaklayanlara yaşatılması, anlatılması ve kolayca ulaşılabilmesiyle insanların boş zamanlarını geçirmeleri, güzel anılarla ve bilgilerle ayrılmaları sağlanacaktır. Öte yandan insanların farklı arzu ve isteklerinin bulunması toplumsal ve kişisel çevrelerinden kaynaklanmaktadır. Araştırma neticesinde Afyonkarahisar'a belirli bir grup ya da aile olarak gelenlerin tercihlerinde destinasyona özgü nedenlerin ön planda olduğu görülmüştür. Destinasyona dayalı nedenlerle ili tercih edenlerin oranı fazla olup destinasyona özgü özelliklerden olan "rekreasyon amaçlı görmek ve yapmak istediklerimin bulunması" düşük orandadır. Öte yandan termal kaynaklar zemininden turistik arzın gerçekleştiği bir başka deyişle turizm talebinin nedeninin termal kaynak olduğu görülmüştür.

Turistlerin Afyonkarahisar'a geliş sebepleri tatil, sağlık ve iş amaçlıdır. Rekreatif amaçlı gelişler ise ikincil sebepler arasında en az düzeydedir. Tarihi alanların ziyareti ve doğal çevre faaliyetleri olarak insanların tercihlerine hizmet edebilecek kaynaklardan özellikle 
Başkomutanlık Tarihi Milli Parkı dâhilindeki alanların etkin tanıtımı turist talebinde etkili olacaktır. Kültür amaçlı ziyaretlerde bulunan turistlerin eğitim düzeyi yüksek ve ziyaretlerinde daha uzun süre konaklama yaparak öncelikli tercihleri tarihi sit alanları ziyaretidir (Nyaupane vd., 2006: 91). Bu yönden bakıldığında Afyonkarahisar'ın sahip olduğu rekreasyon alanları ve faaliyetleri arasında tarihi alanların azımsanmayacak düzeyde olması ancak ziyaretin düşük düzeyde kalıyor olmasında kişisel nedenlerin ötesinde destinasyon kaynaklı nedenlerin varlığına işaret etmektedir.

Doğal çevre etkinlikleri için sağlık kulübü gibi tutundurma araçlarıyla insanları açık alan etkinliklerine yönlendirerek sağlıklı yaşam için sunulan termal tedavi anlayışına yeni bir boyut kazandırılmış olacak ve insanların destinasyonu "sudan gelen sağlık" yerine "Afyon'dan gelen sağlık" şeklinde bütün olarak anımsamalarını sağlayacaktır. Böyle bir tutundurma ve arzın insan yaşamı içerisindeki beşeri ilişkilerine de olumlu etki etmesi kaçınılmaz olacak ve insanların sosyal ortamlar yaratmalarına imkân sunacaktır. İnsanların merak ettikleri ve ilgi duydukları alanlara seyahat etme eğilimleri yüksek olacaktır.

Tarihi ve kültürel varlıklara ilgisi olan ve farklı kültürleri tanımayı önemseyen insanların merakının bu alanları ziyaret kararında kültürel varlıklar önemlidir (Avan, 2010: 122). Afyonkarahisar'ın sahip olduğu coğrafi konum özelliği ve zengin termal kaynaklarının yanı sıra birçok farklı tarihi dokuyu bir arada barındırması, açık hava müzesi durumundaki alanlar ve kendine özgü kültürel özellikleri ve yöresel lezzetlerinin bulunması bir firsattır. Bu kaynakların insanların merak ve ilgi süzgecine dâhil edilmesi termal kaynaklar ve sağlık nedeniyle gelenlerin temel amacının yanı sıra doğal çevre kaynak kullanımının sağlanmasıyla özellikli bir yer olduğu algısının yaratılmasına olanak sağlayacaktır.

İnsanların günlük hayatlarında yapmış oldukları rekreasyon faaliyetlerini tatillerinde de rahatlıkla yapabilmeleri destinasyon bağlılığına katkı sağlayacaktır. Özellikle ulaşım konusunda sıkıntı yaşayan devre mülk tesis ziyaretçilerinin bu sorununu ortadan kaldırmaya yönelik yerel yönetimlerle birlikte sorunun çözümlenmesi il ekonomisinin lehine olacaktır. Frigya, Çavuşbaş, Başkomutanlık Tarihi Milli Parkı veya Akdağ Milli Parkı'nın bulunduğu alan ve çevrelerinde zaman geçirilebilecek üst yap1 yatırımlarının gerçekleştirilmesi de bu bölgeye olan ilgi ve memnuniyeti arttıracaktır.

Turistik anlamda termal kaynakların arzının yanı sira rekreasyon kaynak arzı ile boş zaman değerlendirebilecek ve merak edilen bir yer haline gelmesi ancak tanıtım ile sağlanacaktır. İlgi eksikliğinin sebebi bilgi eksikliğidir. Rekreatif alanlarda daha fazla vakit geçirilebilmesi bu alanlardaki tesis yatırımlarına bağlıdır. Ayrıca yöresel lezzetlerin sunulduğu 
restoranlar ve hediyelik eşya gibi ürünlerinde sunulması gerekliliktir. İl için büyük değeri olan Karahisar kalesinin, Dazkırı halılarının, Çavuşbaş mimarisinin, Frig Kaya anıtlarının minyatürlerinin çeşitli özellikte, farklı desende ve kullanıma yönelik ürünlerinin yapılması ve arzı bu alandaki eksikliği kapatacaktır.

Tarihi, doğal, kültürel varlıklarının yerel, bölgesel veya ulusal girişimcilerce ekonomiye kazandırılması ve potansiyelinin değerlendirilmesi ile turizm anlamında yol üstü güzergâhı olma ve termal kaynak potansiyelinden kaynaklanan üstün yönlerine bir yenisini ilave edecektir. Mevcut müzelerin bakım ve düzenlemelerle çekici hale getirilerek turistlerin "görmeden dönme" şeklindeki düşüncelere sahip olması sağlanacaktır. Başkomutanlık Tarihi Milli parkı, Frig vadisi gibi alanların pazarlanması ve arzı konusunda komşu illerle işbirliği taraflara avantaj sağlayacaktır. Özellikle paket tur beklentisinin karşılanması amacıyla ürün gruplarının paket turlar olarak bölge ziyaretçilerine sunulması, yatırım ve arz sorunlarının da birlikte ortadan kaldırılmasıyla "kazan-kazan" durumu görülecektir.

Kervankıran (2011: 326) mevcut arzın yanı sira yeni turizm alanlarının geliştirilmesi gerekliliğine işaret etmiş̧ir. Sektörel anlamda yeni alan ve faaliyetlerin arz ve pazarlama ile bu konu sorun olmaktan çıacaktır. Elde edilen sonuçlar Kervankıran (2011: 318)'ın çalışmasında ulaştığı sonuçlardan olan tanıtamama ve iyi pazarlamama sonuçlarıyla örtüşmektedir. Belirli yerlere turlar düzenlenmesi, "her güne bir aktivite" şeklinde sloganlarla insanların turistik anlamda harcadıkları zamanın daha fazla donatılması sayesinde "termal su ve güzel bir tatil için Afyon'a gidilir" inanışının kazandırılması sağlanacaktır. Şehirleri panoramik bir yerden izlemek insanlar için güzel bir deneyimdir. Bu konuyla bağdaşan altyap1 yatırımı gelenlerin yapmak istedikleri bir aktivite olmasını sağlayacaktır. Rekreasyon alanlarından en fazla bilinen Karahisar kalesinin basamak sayısının fazlalığı ve ötesinde dik bir yapıya sahip olması zirveye çıkmayı zorlaştırmaktadır. Karahisar için herkesin rahatlıkla zirveye çıkabileceği bir yatırım yerinde olacaktır. Turistlerin en fazla bildiği alan Karahisar kalesi olsa da en fazla gidilen alanın alışveriş merkezi olması sorun göstergesidir.

Araştırma sonuçlarına göre ilin sahip olduğu rekreasyon alan ve faaliyetlerinin talep üzerinde (Geliş Sebebi) etkisinin olmadığı konaklama süresine düşük bir etkinin olduğu ve ziyaretçilerin öncelikli tercih nedenlerinin termal kaynaklar olduğu görülmüştür. Turistlerin ilin rekreasyon alan ve faaliyetleri konusundaki bilgi düzeyleri yüksek olmamakla birlikte ilin mevcut rekreasyon kaynaklarının ve bunlara katılımın konaklama süresi üzerinde etkisi (\%20 katılım oranına karşın, konaklama süresine \%4 etki) yok denecek kadar azdır. Konaklama süresine 
etki eden faktörlerden birisi olan destinasyon rekreasyon alan ve faaliyetlerinin incelenmesi hususu önem arz etmektedir. Yol üstü güzergâhı olması, yakın çevresinde büyük şehirlerin olması ve termal kaynakların arzı avantajlarıyla turistik çekicilik sağlansa da rekreasyon alan ve faaliyetlerinin kullanılması hususunda yetersizdir.

Araştırmanın ilgili literatüre sağladığı katkılar, mevcut durumda Afyonkarahisar'ın termal dışı rekreasyon alan ve faaliyetlerinin konaklama süresi üzerinde çok düşük bir etkisi olup, turizm talebi üzerinde etkisi yoktur. İnsanların günlük hayatta tercih ettikleri rekreasyon kaynaklarına büyük ölçüde cevap verebilecek alan ve faaliyetler bulunmakla birlikte etkin bir şekilde arz ve pazarlama sorunu vardır. Mevcut rekreasyon kaynakları konusundaki arzın yetersizliği konaklama süresinin kısalığ 1 sorununu ortadan kaldırmada yetersizdir.

İlgili literatürde ilin rekreasyon alan ve faaliyetlerinin konaklama süresi üzerine etkisi ve etkiyi ölçmeye yönelik bir çalışma bulunmamaktadır. Turizm talebi üzerinde kültürel varlıkların etkisini ölçmeye yönelik çalışmalar (Avan, 2010; Öter ve Özdoğan, 2005) bulunmaktayken, rekreasyon alan ve faaliyetlerinin konaklama süresine etkisini ölçen bir araştırma bulunmamaktadır. Ayrıca araştırma ilin mevcut alan ve faaliyetlerin bilinirliğini ortaya koymakla birlikte turistlerin ilin rekreasyon alan ve faaliyetlerine katılım düzeyini ölçmekte, katılmayanların nedenlerini saptama ile katılanların düşünce ve algılarını ortaya koymaktadır. $\mathrm{Bu}$ hususlarda gerek yıllara göre farklılıkların ölçülmesi, gerek farklı destinasyonlara yönelik çalışmaların yapılması ile kıyaslamalar yapmaya olanak sağlayan çalışmalar gerekmektedir. Son olarak araştırma daha sonraki yıllarda yapılacak çalışmaların geliştirilmesine katkı sağlayacaktır.

\section{Kaynakça}

Afyonkarahisar Belediyesi, (2012). İklimi. 22.03.2012, http://www.afyon-bld.gov.tr/tr/icerikdetay/6/6/iklim.aspx

Afyonkarahisar Kütüğü, (2001). Afyonkarahisar: Afyon Kütüğü, Cilt I-II. Afyon Kocatepe Üniversitesi. Afyon.

Alegre, Joaquin. ve Pou, Llorenç. (2006). The Length of Stay in the Demand for Tourism. Tourism Management. 27, 1343-1355.

Altunişik, Remzi, Coşkun, Recai., Bayraktaroğlu, Serkan. ve Yildirim, Engin. (2010). Sosyal Bilimlerde Araştırma Yöntemleri. Sakarya: Sakarya Yayıncılık, 6. Baskı.

Argan, Metin. (2007). Eğlence Pazarlaması. Ankara: Detay Yayınc1lik. 
Aslan, Zeynep. (1993). Sanayileşme ve Kentleşmenin Doğada Rekreasyon Faaliyetlerine Duyulan Gereksinimi Arttırıcı Etkisi. Ekoloji: Çevre Dergisi. 8, 22-24.

Avan, Ali. (2010). Konya'yı Kültürel Amaçlarla Seyahat Eden Yabanc1 Turistlerin Satın Alma Karar Sürecinin Değerlendirilmesi. (Yayınlanmamış Yüksek Lisans Tezi). Afyon Kocatepe Üniversitesi Sosyal Bilimler Enstitüsü. Afyonkarahisar.

Aytaç, Ömer. (2002). Boş Zaman Üzerine Kuramsal Yaklaşımlar. Frrat Üniversitesi Sosyal Bilimler Dergisi, 12 (1). 231-260.

Brey, Eric. T. ve Lehto, Xinran. Y. (2007). The Relationship Between Daily and Vacation Activities. Annals of Tourism Research, 34 (1). 160-180.

Butler, R. W. (1980). The Concept of a Tourism Area Cycle of Evolution: Implications for Management of Resources. Canadian Geographer, XXIV, (1). 5-12.

Demirci Orel, Fatma. ve Yavuz, Mehmet Cihan. (2003). Rekreasyonel Turizmde Müşteri Potansiyelinin Belirlenmesine Yönelik Pilot Bir Çalışma. Çukurova Üniversitesi Sosyal Bilimler Enstitüsü Dergisi. 11 (11). s. 61-76.

Hazar, Atila. (1999). Turizm İşletmelerinde Animasyon: Rekreasyon, Animasyon Teorisi ve Uygulamalı Animasyon Teknikleri. Ankara: Detay Yayıncilik.

İlasli, Ahmet. (2001). Afyonkarahisar Tarihi-İlk Yerleşimden Roma Dönemine Kadar Afyonkarahisar. İçinde Afyonkarahisar: Afyon Kütüğü, Cilt I. Afyon Kocatepe Üniversitesi. (83-96). Afyon.

Karaküçük, Suat. (2005). Rekreasyon: Boş Zamanları Değerlendirme. (5. Bask1). Ankara: Gazi Kitabevi.

Kaymakçi, Salih. (2011). Afyonkarahisar'da İlk Tunç Çağı Çömlek Kültürü. Tarihin Peşinde: Uluslararası Tarih ve Sosyal Araştırmalar Dergisi, 5, 197-214.

Kentsel Sit (b.t.). Afyonkarahisar. İçinde Afyonkarahisar Valiliği İl Kültür ve Turizm Müdürlüğ̈̈ ve Afyonkarahisar Belediyesi Kültür ve Sosyal İşler Müdürlüğü Ortak Basım Broşürü.

Kervankiran, İsmail. (2001). Afyonkarahisar İlinin Başlıca Doğal, Tarihi ve Kültürel Kaynaklarının Sürdürülebilir Turizm Açısından Değerlendirilmesi. (Yayınlanmamış Doktora Tezi). Afyon Kocatepe Üniversitesi Sosyal Bilimler Enstitüsü. Afyonkarahisar. 
Kozak, Nazmi, Kozak, Meryem Akoğlan. ve Kozak, Metin. (2001). Genel Turizm: Illkeler - Kavramlar. Ankara: Detay Yayıncılık.

Kültür ve Turizm İstatistikleri, (2012). 19.09.2012, http://sgb.kulturturizm.gov.tr/TR,15229/turizm-istatistikleri.html

Mansuroğlu, Sibel. (2002). Akdeniz Üniversitesi Öğrencilerinin Serbest Zaman Özellikleri ve Dış Mekan Rekreasyon Eğilimlerinin Belirlenmesi. Akdeniz Üniversitesi Ziraat Fakültesi Dergisi. 15 (2). 53-62.

Nyaupane, Gyan. P., White, Dave. D. and Budruk, Megha. (2006). Motive-based Tourist Market Segmentation: An Application to Native American Cultural Heritage Sites in Arizona, USA. Journal of Heritage Tourism, 1 (2). 81-99.

Olali, Hasan ve Timur, Alp. (1988). Turizm Ekonomisi. İzmir: Ofis Ticaret Matbaacılık San. Ltd. Şti.

Oppermann, Martin. (1995). Travel Life Cycle, Annals of Tourism Research. 22 (3). 535-552.

Ozankaya, Özer. (1980). Toplumbilim Terimleri Sözlüğü. (2. Bask1). Ankara: Türk Dil Kurumu Yayını.

Öter, Zafer. ve Özdoğan, Osman. N. (2005). Kültür Amaçlı Seyahat Eden Turistlerde Destinasyon İmaj1: Selçuk-Efes Örneği. Anatolia: Turizm Araştırmaları Dergisi, 16, (2). 127-138.

Özdamar, Kazım. (1999). Paket Programlar İle İstatistiksel Veri Analizi. (2. Baskı). Eskişehir: Kaan Kitabevi.

Sabbağ, Çiğdem. ve Aksoy, Elif. (2011). Üniversite Öğrencileri ve Çalışanların Boş Zaman Etkinlikleri: Adıyaman Örneği. Mehmet Akif Ersoy Üniversitesi Sosyal Bilimler Enstitüsü Dergisi. 3, (4). 10-23. Basımevi.

Sağcan, Mustafa. (1986). Rekreasyon ve Turizm. İzmir: Cumhuriyet

Seaton, A. V. ve Palmer, Christine. (1997). Understanding VFR Tourism Behaviour: The First Five Year of the United Kingdom Tourism Survey. Tourism Management. 18 (6). 345-355.

Sung, Heidi. H., Morrison, Alastair. M., Hong, Gong-Song ve O'leary, Joseph. T. (2001). The Effects of Household and Trip Characteristics on Trip Types: A Consumer Behavioral Approach for Segmenting the U.S. Domestic Leisure Travel Market. Journal of Hospitality and Tourism Management. 25 (46). 45-68.

Ural, Ayhan. ve Kiliç, İbrahim. (2011). Bilimsel Araştırma Süreci ve SPSS ile Veri Analizi. Ankara: Detay Yayıncılık. 
M. Sandıkçı vd. / Afyonkarahisar'ın Rekreasyon Alan ve Faaliyetlerinin Konaklama Süresi Üzerindeki Etkisi

Ünal, Metin. (2012). Afyonkarahisar Konaklama İstatistikleri 20112012. 02.07.2012, (Kültür ve Turizm Müdürlüğünden E-Posta Yoluyla Edinilmiştir).

Williams, Allen. M. ve Shaw, Gareth. (2009). Future Play: Tourism, Recreation and Land Use. Land Use Policy. 265, 326-335. 